УДК 821.163.41.09

https://doi.org/10.18485/godisnjak.2020.15.5

Василије К. Милновић*

Универзитет у Београду

Универзитетска библиотека „Светозар Марковић”

Центар за науку, Београд
Оригинални научни рад

Примљен: 15. 09. 2020.

Прихваћен: 10. 11. 2020.

\title{
ХУКА БАРБАРОГЕНИЈА: ДОСЛЕДНА РАДИКАЛНА УМЕТНИЧКА ПРАКСА ЗЕНИТИЗМА
}

Тема овог рада јесте промишљање домета и досега стваралаштва зенитизма, као оне авангардне теоријске платформе која на најубедљивији начин сведочи о расапу који се дешава унутар укупне српске авангардно-модернистичке парадигме. Доследност и радикалност зенитистичке стваралачке праксе тако потврђује јединственост зенитизма у контексту европске авангарде, али и српске културалне матрице. На тај начин, указује се реална потреба за ревалоризацијом зенитистичког стваралаштва, како у његовом експлицитно-теоријском виду, тако и у самој имплицитно-креативној изведби. Ово нарочито важи с обзиром на актуелност те стваралачке праксе у односу на савремене токове уметности и с обзиром на аутентични пројективно-футуролошки карактер зенитизма.

Кључне речи: зенитизам, Зенит, Љубомир Мицић, манифест, култура тоталног раскида, оптимална пројекција, интердисциплинарност.

*milnovic@unilib.rs 
Ми путујемо из Хаоса да створимо Дело

(Љубомир Мицић,

Манифест зенитизма)

Зенитизам је тоталност! - то би постојећем тоталитету европске традиције, зенитизам као покрет, претпоставио. У том смислу, зенитизам је један од ретких авангардних покрета са широко постављеном и до танчина пројицираном теоријском основом. На ову основу накнадно су калемљени авангардни стваралачки продукти, чија намера није била да постану грађа за класично уметничко вредновање, него да оправдају теоријски зацртан авангардни циљ. Стога су све критике поетике овог покрета (уколико изузмемо оне засноване на личним анимозитетима), без обзира говоримо ли о тадашњим или каснијим рецепцијама зенитистичког стваралаштва, по правилу промашивале мету, јер су овај покрет вредновале у границама уметности и то махом књижевности, иако он већ чињеницом своје доследне авангардности, то никада није био. Зенитизам je, тако, најрепрезентативнији и најдоследнији домаћи авангардни покрет, будући да ни у једном тренутку није упао у замку етаблирања у још-један-уметнички-покрет и да се доследно држао чисто авангардног пута тоталности, што спаја две крајње тачке: тотални раскид с традицијом и авангардну оптималну пројекиију. Наиме, с једне стране, како Петер Биргер у својој студији закључује, одсудна карактеристика авангарде јесте захтев за одбацивањем целокупне „институције културе” (в. Биргер 1998). С друге стране, њен циљ јесте стварање једног „неограниченог уметничког дела". Како утврђује Александар Флакер, авангарда се декларативно залаже за потпуну метаморфозу целокупног друштва, културе и уметности, у правцу својеврсне свеобухватне естетске револуције, те у том смислу има пројективно-футуролошки призвук. За ову круцијалну карактеристику авангарде Флакер проналази адекватан термин: оптимална пројекиија. У својој књизи Поетика оспоравања, Флакер даје и историјат термина. Према Флакеру, овај појам је настао у дијалогу чешких и словачких русиста на симпозијуму у Модрој крај Братиславе 1967. године. Тада је чувени совјетски семиолог Јуриј Лотман у свом експозеу истакао потрагу за, како је он рекао, оптималном варијантом, као суштинску карактеристику науке и уметности у доба превласти и доминације авангарде. Флакер даје и дефиницију: „Оптимална пројекција не означује идеално структурирани 
простор будућности, она га не настоји дефинирати, већ означава кретање као бирање 'оптималне варијанте' у превладавању збиље" (в. Флакер 1984). Потврду овог својеврсног позитивног пола авангарде можемо пронаћи у бројним програмско-манифестативним исказима авангардиста, реализацијама и изгледу бројних авангардних часописа и публикација, као и у имплицитном домену самих авангардних дела.

Овај је пут, у случају зенитизма, симболисан једним појмом или једним имагинарним ликом, који по својој снази превазилази чак и сам покрет који га је отелотворио. То је Барбарогеније, авангардни нови варварин-спасилац, уништитељ и стваралац истовремено, својеврсна метафора, али и спецификум аутентичног српског духа авангарде. Име овог лика зенитизам по свему судећи има да захвали визионарском духу Бошка Токина.

Да ли је оваква теоријска заснованост поетике зенитизма последица филозофске вокације њеног творца, тек Љубомир Мицић, директор-уредник часописа Зенит - „Првог балканског часописа у Европи и првог европског часописа на Балкану" (касније часопис добија поднаслов „Међународни часопис за зенитизам и нову уметност”), који је у периоду од 1921. до 1926. излазио у 43 броја, почев од фебруарског броја 1921. у Загребу - био је ауторитарни зенитистички лидер и духовни вођа/гуру овог покрета.

Мицић је већ и пре активности око централног зенитистичког медијума - часописа Зенит - био познат као стваралац. Објављивао је у Кьижевном југу, Критици, Савременику, као и у међународним ревијама Agramer и Tagblat, а објавио је и две књиге песама Ритми мојих слутња (1919) и Спас душе (1920), с предговорима Тина Ујевића и драмски спев Источни грех. Сва ова дела, без већих одступања, можемо уврстити делом у српску предавангарду, делом у прву фазу српске авангарде и то ону експресионистичку, а чак и прва послератна антологија нашег модерног песништва је регистровала Мицићеву предзенитовску поезију (в. Annie 1920). Стихови који се у овој поезији могу тумачити као експресионистички, звучали су у нашој средини ново и модерно, и у том смислу су за нас значајни, мада се реално јавља са извесним закашњењем у односу на нпр. немачку поезију, од које га читав један ратни вихор дели.

Међутим, први Мицићев зенитистички текст је, сходно самим принципима покрета, програмски. То је, заправо, текстуални уводник у прву свеску часописа Зенит, под насловом Човек и уметност. Ово је текст у коме ће први пут бити формиран појам - зенитизам. Овај појам још увек, додуше, неће садржати сву ону количину тоталног раскида с традицијом 
који ће накнадно бити у њега инкорпориран, него је још, пре свега, реакција на протекла ратна збивања, пуна горчине и резигнације. Термин је објашњен овлаш и уопштено, као „инкарнација духа и душе императив са највишим изражајем у уметничком делу” (Мицић 1921 (1): 1) Везаност за традиционално схваћену уметност, очигледна је, али искључиво као још нејасна тежња за њеним превладавањем и „стварањем највећих облика”, на доминантном фону културе тоталног раскида. Стога нешто касније Мицић пише: „Изнад експресионизма диже се зенитизам - уметност која је афинитивна - уметност која значи тоталност" (Мицић 1921 (3): 9).

За промоцију ове нове „тоталне уметности” пре свега ће послужити основно гласило зенитистичког покрета, часопис Зенит (поред самог часописа постојала је и зенитистичка продукција у оквиру „Библиотеке Зенит”), најзначајнија авангардна, али и шире културална публикација у нас и званично једна од најзначајнијих таквих у Европи, на чијим страницама ће се као сарадници појављивати највећи авангардни духови Европе онога времена (неки од сарадника су били: Иван Гол, Александар Архипенко, Марк Шагал, Василиј Кандински, Ел Лисицки, Ласло Мохољ Нађ, Карел Тајге, Ханес Мејер, Робер Делоне, Соња Терк Делоне, Луј Лозовик, Албер Глез, Серж Шаршун, Август Чернигој, Јосип Сајсел итд.). Заједничко свима њима биће поетика авангардне културе тоталног раскида, уз неминовно признавање превазиђености раних европских авангарди, што истовремено доприноси афирмацији новог потенцијално глобалног покрета - зенитизма: „Нова уметност од пре рата (мисли се на фовизам, кубизам, експресионизам или футуризам - прим. аутора) никако не може да се настави тамо где је прекинута... Зато је потребна нова мобилизација поратне атмосфере духова, јер нова уметност није ванвременска" (Мицић 1921 (10): 11). Та „поратна атмосфера духова” била су заправо она иста разочарања у европску вредносну парадигму, са свим традиционалним системима вредности које она подразумева, која је у српској култури већ била инаугурисана огорченим стиховима Милоша Црњанског у Лирици Итаке (1919). С друге стране, осетљиви сензибилитет уметничких природа није могао остати индиферентан према општем техничком напретку човечанства, према новим, модерним феноменима као што је „аероплан”, филм или општи развој електротехнике. Биће да је управо ова савременост идеја, манифестована на страницама Зенита, била један од круцијалних разлога фуриозној афирмацији зенитизма у контексту европских авангардних покрета и његовом брзом превазилажењу југословенских граница и укључивању у заталасане токове европских авангарди. 
На свом европском путу, међутим, зенитизам ће веома брзо бити потпомогнут веома моћним савезником. Наша књижевна историографија, чини се, још увек слабо наглашава, у контексту брзе европске афирмације зенитистичког покрета, значај Ивана Гола, великог европског експресионистичког уметника и интелектуалца, чији се утицај у то доба у Европи пореди са утицајем Гијома Аполинера из времена прве, предратне етапе у развоју европске авангарде. Како нас у засебном тексту првог броја часописа обавештава Бошко Токин, најзначајнија поетска збирка овог песника је била Panamakanal, из 1913. (в. Токин 1921 (1): 5). Овај немачко-француски авангардист је провео године рата у Швајцарској, у друштву Штефана Цвајга, Џејмса Џојса и Ромена Ролана, коме је чак и посветио свој Реквијем за европске мртве, да би након рата прешао у Париз. Својим декларативним напуштањем експресионистичког европског покрета и активним придруживањем зенитизму, Гол ће нашем покрету дати, као један од највећих експресионистичких песника запада, огромни међународни кредибилитет и као ниједном домаћем уметничком покрету пре неслућене могућности експресне интернационалне афирмације. Можемо ли данас уопште да замислимо било какав аутентично домаћи уметнички покрет који би у својим редовима имао једно од најкрупнијих имена из европске уметничке продукције, што би, опет, иницирало и сарадњу тог нашег покрета са највећим именима данашњице?

Сарађујући већ од првог броја Зенита са песмом на немачком Der Mensch vor dem Meer (Човек из мора), Гол ће писати Мицићу: „Драги друже! Ваш Зенит наткриљује плаветнилом бледило Европе. Он пали, он пламти сунцем у свим срцима, Зенит је чињеница" (Goll 1921 (1): 3). Предосећајући да је експресионизам, у новој констелацији ствари, превазиђен, Гол се придружује зенитистичком покрету: „Експресионизам. Лунапарк из картона и садре, са свим зачараним дворовима и људском менажеријом - руши се... Експресионизам је прорешетана барикада. Експресионизам је пропали ратни лихвар” (Гол 1921 (9): 2). Овај чланак - „Реч као почело - покушај нове поезије" - истовремено је објављен и у часопису Nue Rundschau у Берлину и у вези је са претходним Головим зенитистичким текстом „Espresionizam stribt” (Експресионизам је умро) (в. Goll 1921 (8)).

Поред Љубомира Мицића и Бошка Токина, Иван Гол ће се активно укључити и на теоријском нивоу, у сам развој појма „зенитизам”, објављујући свој прилог у Манифесту овог покрета, који ће бити посебно публикован, на немачком, на првој страни петог броја Зенита. Од осмог броја, он ће по сопственој жељи приступити редакцији Зенита и постати заступник зенитизма за западну Европу. Као ко-уредник, он ће заједно са 
Љубомиром Мицићем фигурирати све до четрнаестог броја, помажући песничкој пракси зенитизма. Поред песничких прилога и теоријских чланака, овај песник ће у Зенитовој библиотеци „Колекција међународних зенитиста", као другу свеску, 1921. године, објавити збирку Paris brennt (Париз гори), са значајном графиком-илустрацијом Михаила С. Петрова „Данашњи звуци”.

Иако ће убрзо прекинути сарадњу са главним уредником, као и већина других интернационалних сарадника Зенита (већ до четрнаестог броја из маја 1922. године, док је Иван Гол још ко-уредник часописа, са Љубомиром Мицићем су, што због поетичких размимоилажења, што због личних сукоба, прекинули сарадњу многи домаћи ствараоци: Растко Петровић, Милош Црњански, Станислав Винавер, Драган Алексић, па чак и један од првобитних стубова зенитизма Бошко Токин), овај песник ће бити једини од великих европских стваралаца који ће се декларативно изјаснити као зенитиста и тако допринети општој афирмацији зенитизма у европским оквирима, чак толико да неки европски прегледи авангардних „изама” цео зенитизам везују искључиво за њега, што наравно не може остати валидно. Ово је свакако разумљива цена радикалног и тврдоглавог затварања у строго националне мотиве и оквире од стране оснивача зенитизма. Једино ће још 1924. године, приликом приређивања „Прве Зенитове међународне изложбе нове уметности", у Београду, Љубомир Мицић успети да окупи велики број интернационалних сарадника часописа Зенит.

Но, суштински развој појма „зенитизам”, уз карактеристичан ватромет манифестативно-патетичних парола, уследиће превасходно у веома битном програмском тексту, који је Љубомир Мицић писао заједно са Иваном Голом и Бошком Токином. У питању је Манифест зенитизма, текст који ће у орбиту европске авангарде лансирати „последњег свемоћног јунака европске романтичарске декаденције” (Јованов 1999: 43), лик Барбарогенија, инкарнације новог варварства, који ће „срушити предграђа великих и кужних западноевропских градова (...) разбити стакла позлаћених дворова - високих торњева бурза и банака...”

Иван Гол, велики прозор зенитизма ка европској авангарди, биће у тексту Манифеста... најрадикалнији у свеопштем захтеву за културом тоталног раскида: „Уништимо цивилизацију помоћу нове уметности. Цела литература цивилизованог доба само је израз свих лажних осећаја који су нас са фразама отуђили од праприроде... Натраг ка праизвору доживљаја... к барбарству! Ми опет морамо постати барбари поезије!”

Бошко Токин ће у свом тексту Манифеста... указати на потребу рушења традиције, укључујући ту и претходне авангарде: „Експресионизам је хтео и хоће дух, спиритуалност и динамичност мистике... А нама треба 
ова пракса; израз битних конструкција. Еманација динамизма здравог, чедног, барбарског."

Манифест... се темељи на бинарним опозицијама као што су: Запад-културе и варваризам-Балкана, мушкост и женскост, модерност и традиционалност итд. У њему се суочава пет политичких категорија: Европа, Балкан, нови човек, словенска раса и свечовечност. Овде је Мицић „извео парадоксални-еклектични левичарско/десничарски рез у западном традицијском универзализму и дошао до потенцијалности модерног локалног, које треба да мотивише, или антиципира ново опште" (Шуваковић 2010: 87). Већ овде, дакле, на зенитистичко-парадоксални начин, антиципирана је парадигма балканизације авангарде зарад глобалних циљева, што ће бити доминанта наредне развијене фазе зенитизма и што ће, у највећој мери, иницирати бројна напуштања овог покрета, али и суштинска неразумевања (тадашња и садашња) ове поетике.

На основу свега реченог, постаје јасно да се појам зенитизам односи на неку врсту синтезе ранијих авангардних покрета: футуро-дадаистичко-експресионистичких и конструктивистичких елемената, са спецификумом у односу на поменуте покрете - да више него они отворено тежи супротстављању тековинама западноевропске цивилизације. Другим речима, авангардна култура тоталног раскида у зенитизму је максимално појачана локалним наслеђем. Ово ће нарочито постати јасно у каснијим Мицићевим текстовима. У Манифесту... је, дакле, појам зенитизма, као уосталом и лик Барбарогенија, још увек општи, без ближих географско-идејних одредница или морално-социолошких узуса, конституисан као сума вечитих сирових снага из које се човечанство може подмладити. Ово је, међутим и једно од општих места авангарде, али и модерне уметности као такве. Уколико је култура тоталног раскида с једне стране овде доминантна, са друге стране јасно је и екскламативно зацртана и оптимална пројекција овог Манифеста... - као химнична вера у човека, као мистично уздање да ће он доспети у Зенит - „највишу инкарнацију Свепостојања”. Ево примера типично мицићевског патетично-паролског фразирања:

Будући човек! Биће син Сунца и Зенита... Песници! Браћо! Зенитисти ви још непознати! Збаците мантије лажи! (...) Зауставите падање човека (...) А, онда када умре и последњи Нечовек онда у свим земљама - у свим градовима, на свим торњевима бродовима - аеропланима - палатама - судницама - болницама - академијама лудницама - лукама... певајте... певајте Химну зенитизма.

Међутим, веома брзо, појам зенитизма постаће много одређенији: „Зенитизам је ослобођење од свију академских окова и признатих, лажи 
европског класицизма и барнумске цивилизације... Зенитизам - нова балканска уметност... Ми нећемо да смо Европејци. Хоћемо: Балканизацију Европе и први откривамо да постоји земља Барбарогенија - Балкан...” (Мицић 1922 (11): 3).

Тако зенитизам, можемо рећи - у својој другој фази - постаје нова балканска уметност, која своју фуриозну силу проналази у балканским источницима. Овакав зенитизам треба да балканизује Европу, треба да постане алтернатива свему западноевропском, свему империјалистичком и капиталистичком, читавој европској традиционалној парадигми; и да доведе до нове уметности, као независног тоталитета, са сопственим принципима, која ће представљати један псеудоколективан израз, супротстављен свему што је лично. Такав зенитизам има и свој симбол, лого или имагинарну идеалну личност - Барбарогенија, великог балканског примитива, који своју надљудску снагу проналази на источно-словенском фолклорном извору.

На први поглед, личност Барбарогенија као симбол зенитизма, нарочито у својој првој фази, унеколико подсећа на оног „младог бога животињства", о коме ће певати, отприлике у исто време, у својој збирци Откровење Растко Петровић. И тамо је фолклорни елемент пресудан. Међутим, непосредно порекло ове фигуре ипак можемо сагледати, не у древним временима, него у ближој прошлости, у контексту тада веома утицајне (нарочито по европску авангарду) Ничеове филозофије. Барбарогеније, дакле, постаје много јаснији уколико га сагледавамо у координатама Ничеовог Übermensch-а: „Култура авангарде (совјетске) прожета је ничеанском темом новог човека, јединством воље и естетичког принципа. Спољашњи рационализам авангарде подупире веровање у натчовечанску моћ уметника/ствараоца, који је у стању да успостави нови естетички поредак у човечанству и у читавом универзуму" (Гројс 1991: 11). Оно што важи за руску авангарду, важи и за зенитизам. Нарочито је убедљива компарација зенитизма са једном струјом руске авангарде. Ради се о специфичном облику руског футуризма, под називом - лучизам.

Ове компарације, које откривају право порекло Мицићевог Барбарогенија, никако нису противречне, како закључује већина тумача. Тако на пример Јасна Јованов закључује: „ничеанска идеја и антиевропски концепт зенитизма, заправо су прва контрадикторност у коју Мицић запада” (Јованов 1999: 44). Заправо, оне јесу противречне, али баш то и чини срж зенитизма као авангардног покрета - противречност, амбивалентност и парадоксалност. Стога се пре можемо сложити са закључком Мишка Шуваковића, који за зенитизам каже: „Мицићев зенитизам има парадоксалне, 
еклектичне и ексцесне идеолошке карактеристике, у најопштијем смислу се може одредити као анархистички приступ који се служи различитим стратегијама провокације у оквиру великих идеологија пансловенства, национализма, ничеанског натчовека, бољшевичке револуционарне реторике, троцкизма и анархистичке номадске стратегије перманентне промене гледишта, облика изражаваға, вредности и идеологија" (курзив В. М.) (Шуваковић 2010: 73). У том смислу, зенитизам на специфичан начин обрађује како наслеђе раних авангарди пре Првог светског рата - у њиховом политички превасходно „десном” дискурсу (нпр.: пракса немачког Der Sturm-a или италијанског футуризма) - тако и креације доминантно „левих” послератних авангарди (нпр.: међународна пракса дадаизма или совјетски конструктивизам).

Авангардна култура тоталног раскида у зенитизму сада постаје јасан отклон према свим западноевропским традицијама, укључујући и све њене домаће епигоне, у којима Мицић препознаје само интерес западноевропског капитала и империјалистичке тенденције: „Светска буржоазија никако неће да призна да је једино Лењиново гледиште на светски рат било тачно и да остаје тачно. Нагон империјализма је свиреп и без скрупула. Он је злочиначки. Капитал је оруђе помоћу кога се колективни злочин преводи у дело. Удружени, капитализам и империјализам даје неман ратова... Храна капитализма је храна друштва и пљачка туђега рада. Рана империјализма је пљачка човечанства и пљачка туђе слободе... Да Србија у светском рату није играла на карту енглеско-француског капитала нас би нестало са земље... Ах, Србијо! Није њихова љубав била ради нас на нашој страни него ради колонија и осталих њихових 'виталних интереса"” (Мицић 1925 (37): 3). Западноевропској парадигми, са свим подразумевајућим елементима, Мицић супротставља балканског Барбарогенија, предводника варвара:

Молијеру скидамо мирисномасну перику! Остаје празна глава краљевског и дворског добављача лудости

Дантеу деремо католичанску црну мантију! Остаје голотиња црквеног Луцифера који само за себе жели рај а за све друге пакао

Шекспиру чупамо италијанску брадицу: остаје само патос лорда Бекона и хомосексус данског краљевића Хамлета с отрцаним „бит ил не бит”

Канту вадимо мозак и режемо пупак: остаје „здрави разум” германске филозофије на вршцима наших тупих ноката

Краљевића Марка трпамо у Видовдански Храм, а Мештровића у ректорат Академије за уметност. Тако их се најбоље решавамо јер у музејима они први треба да су балзамовани за вековечност

Шта хоће ти дивљаци зенитисти? 
1. Супериорни став према досадашњој штићеници Мадаме Европи

2. Посвемашње негирање и одбацивање вањско математско физичке цивилизације

3. Нововременска афирмација источно-метакозмичке идеје Новочовека

4. Васкрес југобалканског пратипа Човекхероја у унутрашњој духовној инкарнацији БАРБАРОГЕНИЈА

Зенит Манифест

У овој етапи зенитизма, дакле, очигледно је да варварима постаје светски пролетеријат, али превасходно онај источно-словенски: ,„.. баш ми, Варвари Срби и Руси, у првом реду ћемо извршити револуцију у области поезије и уметности, у области културе за ново човечанство... Ми ћемо немилосрдно разорити прастаре форме и унети варварске сировине..." (Мицић 1926 (41): 19).

Укалупљивање зенитизма у „леву” идеолошку матрицу од стране Мицића, као и радикални отклон од било какве западноевропске парадигме, јесу две суштинске одреднице развијене етапе зенитизма. Што се тиче прве карактеристике, један од најбољих познавалаца зенитистичког покрета, али и један од ретких људи из Мицићевог окружења након његовог егзила, Зоран Маркуш, овако објашњава поменуту особину: „Еволуирање зенитизма у идеолошком правцу, тј. стављање варварства и Барбарогенија у социолошки и политички контекст представља новину. Иако ни Мицић, као ни други југословенски зенитисти нису припадали комунистичком покрету, а њихове везе са руском авангардом биле су уметничке природе, у знаку солидарности напредних покрета, зенитизам је испољио ултралеви радикализам, повезао став са акцијом, естетику са идеологијом и политиком (појава иначе тако ретко на страницама историје уметности) и рушења базе и надградње грађанског друштва идентификовао са оним друштвеним снагама, које су, по природи историјског развоја, за то предодређене. Тиме се он одваја од свих европских покрета" (Маркуш 2003: 54). Уосталом, ово је и био разлог гашења часописа Зенит. Непосредни повод је био текст др М. Расинова „Зенитизам кроз призму марксизма” (в. Расинов 1926 (43): 18). Након тога, Мицић бежи у Италију, где исте године бива ухапшен, па потом, на интервенцију „футуристичког оца”, Маринетија и песника и парамилитарног вође Д’Анунција, пуштен. После тога одлази у Париз, где се и настањује. У Паризу ће живети до 1936. и објављивати зенитистичку поезију и прозу на француском језику. Његов последњи ,јавни наступ” био је објављивање Манифеста србијанства, у новопокренутом часопису Србијанство, 1940. После овога, прекида јавне иступе све до смрти 1971. године, у екстремно оскудним условима живота, у банатском селу Качареву, надомак Панчева. 
Када је реч о другој одсудној карактеристици зенитизма у овом периоду, веома често се, када се говори о зенитизму, наглашава да је управо тај отклон од западноевропске парадигме, уз тежак Мицићев карактер, главни разлог удаљавања највећег броја сарадника Зенита од личности и дела његовог уредника. Каже се обично да се Мицић својом новом поставком зенитизма и фигуре Барбарогенија затворио у балкански, чак србијански оквир, и тако удаљио од концепта зенитизма као изворно нашег, а европског, авангардног покрета. Изричито негативан критички текст Радомира Константиновића, у том смислу може бити репрезентативан (в. Константиновић 1983). Тек у најновије време, заступљена су другачија стручна мишљења и настојања да се научно суверено супротстави таквим твдњама (в. Суботић 1990: 17; Суботић 1997: 32-37). Уосталом, сам је Мицић, у контексту књижевнотеоријских и књижевноисторијских поставки жестоко пострадао, како у домаћим, тако и у интернационалним размерама. Тако, на пример, у неким европским публикацијама, зенитистички сарадник, који јесте у једном тренутку био битна европска полуга зенитизма, Иван Гол, бива проглашен за вођу зенитизма, свакако и због његове интернационалне песничке репутације (в. Portner 1961).

Оно што је, заправо, суштина ове карактеристике зенитизма, јесте чињеница да Мицићево инсистирање на вредностима националног мита и „барбарогенијској” фолклорној парадигми, у поетичком смислу, није значило сужавање стваралачке призме, него напротив - обогаћивање и проширење стваралачких могућности зенитизма, у складу са зенитистичком анархистичком стваралачком праксом, чији је један од основних постулата - константна промена гледишта и домен игре у контексту великих идеолошких парадигми. Та игра треба баш да послужи за спас западне парадигме, као алтернатива доминантној културалној пракси, а њеном предводнику „Барбарогенију, носиоцу несентименталне сирове виталности, чисте вере, непатворене душе, отвореног доброг срца, које са пуно свечовечне љубави ми и Руси уносимо у нови живот новог човечанства" (Мицић 1923 (21): 1), припада историјска улога носиоца и симбола ових тежњи. У том контексту треба тумачити и зенитистичке демонстрације (оличене у личности Ве Пољанског) против предавања немачког новинара Алфреда Кера 1926. године у Паризу, о зближавању немачке и француске културе, као и демонстрације против гостовања индијског песника Рабиндраната Тагоре исте године у Београду, мудраца који је пропагирао јединство Истока и Запада. Зато су у отвореном писму Тагори, браћа Мицић исписала паролу: „зенитизам је против савремене културе и савремене цивилизације” (в. Зенит 1926 (43): 16). 
Ипак, оваква експериментална стваралачка пракса неће бити добро дочекана ни од савременика ни од потоње научне јавности, те ће мит о зенитизму као најразвијенијем аутентично домаћем авангардном покрету лагано пасти у заборав. Томе ће допринети свакако и надреалисти, који су добар део својих постулата проналазили управо у зенитизму, али који су из револуционарних разлога оптималних пројекиија надреализма одбацивали све пре њега. Љубомир Мицић ће у доба њихове превласти продавати француске жилете испред београдске Каленић пијаце. Чак и у најновије време суд о зенитизму неће лако постајати другачији. Тако, несумњиво највећи српски авангардолог, Гојко Тешић, у својој статусној књизи Српска кьижевна авангарда, зенитизму посвећује тек неколико, додуше, врло провокативних пасуса. Указујући на чињеницу да је часопис Зенит „излазио дуже него што је карактеристично за авангардна гласила”, Гојко Тешић поводом зенитистичке критике закључује: „Основно начело те критике своди се на ригидни став о томе како је све оно што се у литератури до тога доба наметало као ново - безвредно, то јест да је зенитизам једина аутентична авангарда, а да су сви антизенитисти само клонови мртве традиције. (...) Мицић је на крају остао сам. У српској литератури двадесетих година XX века он је сасвим сигурно аутор највећег броја зенитистичких манифеста које карактерише жучан и циничан, негативни став како према српској, тако и према европској литератури" (Тешић 2009: 65). Касније у тексту, разматрајући динамику књижевног живота у време најјаче авангардне активности, Тешић изриче још радикалније ставове поводом зенитизма: „Мицић наставља са умножавањем програмских текстова којима, понављањем већ изречених теза, хотимично намеће неку врсту поетичког (зенитистичког) терора" (Тешић 2009: 69). Иако овде нећемо полемисати са несумњивом истинитошћу неких од наведених закључака, ипак је битно нагласити да, уколико зенитизам тумачимо као радикалну уметничку праксу, овакве оцене захтевају додатно објашњење.

Наиме, зенитистичка пракса, у контексту доминантне српске културалне матрице, на најјаснији начин сведочи о расапу који се дешава унутар српске авангардно-модернистичке парадигме. Тај расап се тиче односа према традицији и за савремену културу и уметност он има чак и већи значај од раскола између „старих” и „нових” с почетка века. Као конкретни датум којим се чињенично може означити почетак овог расапа (опет у вези са зенитизмом) може се узети иступ припадника „београдске авангарде”, окупљених око „групе Алфа”, у загребачком часопису Kpuтика, у коме се из прогласа којим маркирају своју програмску посебност (в. Критика 1921 (2): 11.12), може уочити и јасно уметничко раскидање и 
људско разилажење са програмом зенитизма (додуше, у великој мери због личних сукоба са непомирљивим Љубомиром Мицићем). Овај проглас се, међутим, данас заправо може тумачити као отклон од авангардних захтева зенитизма и радикалне уметничке праксе и као придруживање матици која се креће у правцу високоестетизованог модернизма. Другим речима, овим прогласом, „београдска авангарда” се добрим делом одрекла самих захтева авангарде, као радикалне уметничке праксе и претходнице високоестетизованог модернизма, одлучујући се да уместо авангардне културе тоталног раскида са традицијом преузме на себе једну модернистичку реинтерпретацију традиције. Тиме је она, на известан начин, прихватила наметнуту улогу књижевности (као још-једне-уметничке-дисциплине) и самим тим пристала на њен гетоизиран опсег деловања. Разуме се, тиме је и напустила неке од основних авангардних захтева, као што су: интердисциплинарност, револуционарност, експеримент итд. Када се у оквиру ових категорија приступи тумачењу зенитизма, постаје очигледно да се испод зенитистичких ,репетиција” и отклона према било каквом покушају реинтерпретације традиције крије нешто дубље, што и јесте мерило сваке „расне” авангарде.

На тај начин, већ 1922. година је донела трајну поларизацију српске авангардно-модернистичке парадигме. У контексту српске књижевности, тако на пример, као једно од битних почела „нових” поетских учења можемо означити Винаверов рани, предавангардни захтев за ослобађањем српског језика од „вуковске” парадигме и за отклон „нове” језичко-уметничке праксе од онога што би, у недостатку схоластике у нашој традицији, означавало наш аутентични еквивалент њој - метрике и атмосфере епског десетерца. Ово учење ће, међутим, у српском XX веку имати двојаку манифестацију: кроз авангардну радикалну уметничку праксу и кроз модернистичко реинтерпретирање традиције. Зато исти отклон, али на драстично различите начине, демонстрирају, на пример, у годинама 1921/1922: Милош Црњански у Стражилову и Растко Петровић у песмама Откровења.

Међутим, радикалној верзији српске културе - коју својим радом представљају рани Растко Петровић, Љубомир Мицић и други зенитистички аутори, Драган Алексић и остали дадаистички аутори - неће бити дозвољен даљи развој. Бочни удари су били сувише јаки. Љубомир Мицић је завршио у егзилу, Растко Петровић је, за длаку избегавши екскомуникацију „десних”, проглашен за „мртвог” од стране „левих”, Драган Алексић је манифестативно заћутао, заједно са остатком европске даде, да би након Другог светског рата живео у крајње незавидним условима, док је можда 
највећи визионар међу њима, Бошко Токин, завршио на принудном раду на Голом Отоку, од чијих последица ће убрзо по изласку на слободу и преминути. Послератна либерализација у култури је парадоксално значила да ће српски надреалисти спроводити списатељско-есејистичку и научну ревизију међуратног периода, у којој су чак и много блажи модернистички феномени одбацивани и прећуткивани. Зенитизам се у таквој констелацији ствари није озбиљно ни разматрао. Сам Љубомир Мицић је био од друштва презрен и заборављен, остављен да са супругом живи у крајње сведеним животним условима, без пензије и било каквих прихода ${ }^{1}$.

Ипак, прегнућем Зорана Маркуша, који након Мицићевог егзила заснива дугогодишње пријатељство са њим, а потом и посебно важним истраживањима значајних историчарки уметности Видосаве Голубовић и Ирине Суботић, зенитизам ће коначно постати предмет нове научно-уметничке ревалоризације. Ово ће омогућити да се зенитизам као тема отвори на критичко-научном плану, што ће за последицу имати раст свести о значају - чак у интернационалним оквирима - овог нашег авангардног покрета. Његова дефинитивна утемељеност, као најзначајнијег домаћег авангардног покрета, постаје неспорна тек 1983. године, када се у Народном музеју, у Београду, приређује изложба под називом: „Зенит и авангарда двадесетих" (в. Голубовић, Суботић 1983). Колико су радикалној авангарди супротстављања била јака сведочи управо ова изложба, која је чак и у то време изазвала огроман друштвени скандал и жучне реакције још живих следбеника надреализма, али и тадашњег естаблишмента, који је веома јасно препознавао опасан анархо-либерални потенцијал ове авангарде. Ипак, захваљујући овој изложби, први пут у новијој историји, пред очима јавности ће бити приказана скоро читава и до тада непозната стваралачка заоставштина Љубомира Мицића. У новије време, Видосава Голубовић и Ирина Суботић ће посебно дати зенитизму на значају кроз своју уметничко-историјску научну праксу (в. Голубовић, Суботић 2008), а Народна библиотека Србије ће популарисање зенитизма и упознавање јавности са културалним значајем овог авангардног покрета крунисати

\footnotetext{
${ }^{1}$ Упоредити: „У том сложеном душевном животу човека крајње поједностављене физичке егзистенције, наталожило се много горчине и вероватно небројено пута постављених питања: ко све, сем бирократског апарата, стоји иза забрана Зенита, оптужби и прогона? Колико је много труда уложено да би се онемогућио у раду, колико је напада доживео... Не сведочи ли то да га нису сматрали наивним и безопасним супарником, да ли је многима сметао интернационални дух његовог гласила, сарадња од Истока до Запада, све до Јапана, да је покретање нових идеја, нове уметности и новог културног духа имало дубљег смисла од програмских текстова и звонких речи манифеста (Суботић 1981: 1485).
} 
интернет презентацијом свих бројева часописа Зенит (http://scc.digital. nb.rs/collection/zenit).

Радикални отклон од западноевропске културалне матрице у завршној етапи зенитизма, имаће, додуше, један помирљивији тон, појачан самом чињеницом Мицићевог егзила управо у западну Европу, прецизније - Француску, у којој ће од 1927. провести дуги низ година. Заправо, његови тамошњи написи, иако и даље у духу изворног зенитизма, враћају се оном првобитном зенитистичком доживљају стваралачког варварства, налик оном из Манифеста зенитизма. Ово варварство поново превазилази уско националне оквире и постаје синоним и метафора глобалног неопримитивизма. У делу на француском језику из 1928. - Hardi! A la Barbarie (Смело! У Варварство) $)^{2}$, Мицић ће записати:

Нема Истока и Запада! Само Варвара. Постоји само цивилизација и варварство. Треба пробудити наше варварство дубоко успавано. Пробудити спиритуално и креативно варварство. Сви народи имају своје варваре, који су једини ствараоци. Варваре који су спасиоци.

Да ли је ово био Мицићев коначни компромис са стварношћу, у којој није дошло до сукоба Москве и Париза, нити до балканизације Европе, или је у питању нови домен зенитистичке игре, у константној измени идеолошких или поетичких гледишта? - остаје суд на сваком појединачном читаоцу.

Када је реч, конкретно, о поезији зенитизма, треба увек имати у виду да су личности које су биле стубови зенитистичког покрета, пре свих Љубомир Мицић, Иван Гол и Бранко Ве Пољански - били превасходно песници. То је и разлог зашто је зенитизам, осим у манифестативној и теоријској равни, најзначајније домете имао управо у поетској пракси. У ствари, сам Мицић је зенитизам као покрет видео као предодређен за поезију. По њему је у перспективи „зенитизам предодређен за песништво и филозофију, експресионизам за сликарство и музику, а кубизам за скулптуру и архитектуру” (Мицић 1921 (10): 11). Биће да на овакав поглед утиче и лична филозофска вокација, као и лична поетска опредељеност. Теоријско објашњење зенитистичке поетске праксе, у највећој мери ће дати Гол и Мицић.

\footnotetext{
${ }^{2}$ Остала његова дела на француском су: Zeniton, L'Amant de Fata Morgana (1930), Les Chevaliers de Montparnasse (1932), Etre ou ne pas etre (1933), Apres Saraievo. I Expedition puntitive (1933), Rien sans amour (1935) i Barbarogenie le Decivilisateur (1938).
} 
Суштина зенитистичке поезије, према мишљењу њених утемељивача, треба да буде оно што ће Гол именовати као „прајезик”. Очигледно се и овде ради о генералном циљу европске поетске авангарде - потрага за исконским, древним, митским парадигмама којима треба да буде замењена постојећа културална пракса. Заљубљеност у културу примитивних народа Африке или једноставност поезије Далеког истока провејава и кроз зенитизам, баш као што је случај и са поезијом једног Растка Петровића. Појам „прајезика” доима се, дакле, као веома сродан Петровићевом ,језгру подсвести”, Настасијевићевој „родној мелодији”, али и Алексићевом „прапојму”. Каква је онда суштина зенитистичког поетског израза?

„Наш језик треба да буде стрм: стрм, узак, каменит као обелиск. Стрм као зраци подневног сунца. Тврд. Го. И поред тога да још остане песма? Не баш песма, али ритам (курзив: В. М.). Не фрула, али 'бањо' (...) Ми експресионисти знали смо и осећали те потребе али их нисмо решили" (Гол 1921 (9): 2). Очигледно да се и овде, као и у случају дадаизма, али и неких других европских авангарди, суштина поезије преноси са семантике на визуелне и ритмичке феномене. Нешто слично ће се у садашње време дешавати са авангардом на филму: од класичне филмске приче до видео-арта, где управо визуелни и ритмички елементи добијају превагу над сижејним. Дакле, ова поезија треба своју снагу да црпи на првобитним изворима, на сажетој мудрости реченице далекоисточног песништва, на једноставности и аутентичности осећаја примитивних народа. То је онај стваралачки импулс који треба да замени дотрајалу европску артифицијелност и вештачку и неприродну култивисаност. Свака реченица у таквој поетици треба да буде осамљена, неприступачна за било какво додатно значење и сама себи довољна. „Сваки стих осамљен, стога нема више риме, нема строфе итд. Оне уствари нису само постале немодерне и досадне, већ и управо немогуће" (Гол 1921 (9): 2).

Љубомир Мицић ће у својим поетским захтевима бити још радикалнији. У том смислу, његово централно програмско дело јесте Kameгорички императив зенитистичке песничке школе (Мицић 1922 (13): 17). Исти текст Мицић је превео на немачки и њиме се послужио као уводом у немачку свеску Зенита (бр. 16), коју је уприличио због његове посете Немачкој. Такође, исти текст, са неким минималним разликама, коришћен је и као увод Мицићеве збирке Кола за спасавање.

И поред честих реваншистичких пасажа и, данас се чини - беспотребних дигресија, академски тон главнице текста можемо са ове временске дистанце ишчитавати као својеврсну теорију нове лирике. Замишљен као „антиестетика, односно условна естетика”, овај текст је подељен на 
осам вежби. Лирика, добијена из ових вежби, баш као и у случају Растка Петровића, почива на подсвесном или несвесном нивоу људског бића. И у каснијој својој поезији Мицић ће бити веран овоме, што потврђује уводни текст „Ванумна поезија и Антиевропа” у збирци Антиевропа: „Да - на граници 'чистог разума' настаје 'чиста' уметност - нова уметност: зенитизам. Тамо где 'дах чистог разума' не може да допре - тамо је стваралачка зона ванума" (в. Мицић 1926).

Извор, дакле, сваког аутентичног стваралаштва јесте оно што Мицић именује као - „ванум” - мрачна и затамњена област човечије психе. Ми данас не знамо да ли је постојао и колики је био евентуални међусобни утицај Мицића и Петровића. Једино је несумњиво да је постојао њихов обострани утицај на каснију поетику надреализма, који ни до данас у теорији није довољно потенциран. Тек, Петровићево „језгро подсвести” неодољиво подсећа на оно што Мицић обележава као „ванум” и у самом значењу појма и у поетској разради у правцу примарних осећања, примитивизма као потенцираног облика стваралаштва, као и оштре критичке димензије доминантног културалног дискурса, који је, заправо, фалсификат ових аутентичних људских сензација. Леви-Стросове структуралистичке антрополошке студије и специјално његов појам „митеме” свакако су веома применљиве на овакву поезију, као и Лаканова потоња филозофска надградња кроз „пофилозофљење” и стапање структурализма и Фројдове психоанализе.

Додуше, могућност синхроницитета тих година је, такође, велика. Исти случај је, уосталом, и са Мицићевим позивом из Манифеста... о потреби одбацивања предратних авангарди, који се појављује, без међусобних утицаја, исте 1921. године и у Француској и у Русији. У Француској је то текст младих и до тада непознатих сликара Амадеа Озенфонта и Шарла Едуарда Женерета: Apres le Cubisme, а у Русији апел за нову уметност Међународног уреда Одељења ликовних уметности Народног комесеријата за просвету.

Није онда чудно што поезија заснована на појму „ванума” представља променљиво поље на коме царују феномени као што су: парадокс и симултаност. Већ закључак прве вежбе гласи: „Парадокс је елеменат зенитистичког песништва.” На њега се надовезује закључак проистекао из друге вежбе: „Симултана експанзија једновремених и многоврсних догађаја најважнији је елеменат зенитистичког песништва.” Потом следи и пример, који и графички истиче експанзију. Тако бива да се две песничке теме паралелно развијају, тако што се стих а надовезује на стих ц, а стих б се односи на стих д: 
Јури земља својим дивљим светокретом кроз отровни реп нове комете и архипелага звезда.

Умире сунчано срце у рукама времена.

О зашто нисам муња простора да пројурим простор космоса и хаоса онкрај времена и простора?

(Речи у простору)

Идеја симултаности као суштинска теоријска одредница зенитистичке поезије није ипак и зенитистички изум. Симултаност израза је једна од тековина првих фаза европске авангарде. Први је декларативно његов значај открио Гијом Аполинер, елемент симултаности у стваралаштву је потенцирао и кубизам, али је ову идеју, пре свих, прославио футуризам. У том смислу, још једном се потврђује синкретички карактер зенитизма као покрета, оличен у речима Ивана Гола, којима у свом програмском тексту позива зенитизам на „кроћење и гомилање свих 'изама' и треба узети најбоље од свију што се називаху: футуризам, кубизам, креационизам, ултраизам, дадаизам, а предложио бих још и даље: негризам, монголизам, дервишизам, интернационализам" (Гол 1921 (9): 2).

Међутим, постоји и једна значајна разлика у употреби симултаности између Маринетија и Мицића. Наиме, прве зенитистичке песме (укупно 16 песама), објављене су под насловом Речи у простору, 1921. године у Зениту; да би се касније у радикално измењеном виду појавиле у Мицићевој збирци Кола за спасавање. Шта је суштина ових промена у песничкој материји? То је, пре свега, потпуно подређивање поезије теорији. Резултат тога је увек негативан по поезију, разуме се. Симултаност Мицићеве поезије зато се, као данак теоријским поставкама, доима као одвише тврда и непесничка, без икаквих прелаза или благих тонова, далеко од лепршавости и искричавости Маринетијевих симултаних стихова. Међутим, треба разумети и Мицићево настојање да у борби за зенитистичке вредности, у контексту европских авангардних покрета, подреди своје стваралаштво теорији и зенитистичком програму, па и по цену поетичности. Уосталом, сам Мицић ће у својим каснијим збиркама, не пренебрегавајући принципе зенитистичке песничке школе, пронаћи модус стварања којим ће умекшати гвоздену теоријску дисциплину стихова из Кола за спасавање. Већ и самом чињеницом да песме у овим збиркама нису обележене бројевима као у поменутој збирци, већ да свака песма има назив, као и тему, његове збирке Аероплан без мотора и Антиевропа представљају, на известан начин, победу стваралачког принципа над сувом 
теоријом. Стихови Кола... представљају, заправо, неку врсту песничког супрематизма и крајњу консеквенцу зенитистичке песничке школе, одакле није више било могућности неког новог развоја. Наравно, то не значи да Мицићева поезија из ове збирке не поседује чисто поетске вредности. Само је у стиховима Кола... - за разлику од Речи у простору где, како смо видели, имамо случај унакрсне коренсподенције стихова по принципу а-ц, б-д итд., да би се та кореспонденција на крају стопила - постигнута максимално могућа густина симултаности и засебности сваког појединог стиха, у складу са програмским начелима из Категоричког императива... Поновићемо пример који у својој студији наводи и Зоран Маркуш, због његове сликовитости:

(Песма бр. VII)
О Венецијо
ми путујемо у пропаст понора
у поноре висина
ка Сунцу.
На улицама твојим леже мртваци
седам сунчаних мртваца
Сунце је убица.
Далеко негде лутају наша браћа
Квартовима непознатих градова
и траже своју звезду генија.
О како би наша мајка сретна била
да је становала до улице
и осетила синовску љубав.
(Речи у простору)

Након теоријских интервенција, ова песма гласи:

Венеција

Ми путујемо у пропаст понора

Понори и висина

\section{ЗЕНИТ}

На улицама твојим леже мртваци Седам сунчаних мртваца

ЖАЛОСНО ЈЕ МРЕТИ ОД СУНЧАНОГ МЛЕКА Далеко лутају наша браћа

Непозната предграђа

Подземна железница

Зелена светла стреме у тунелима 


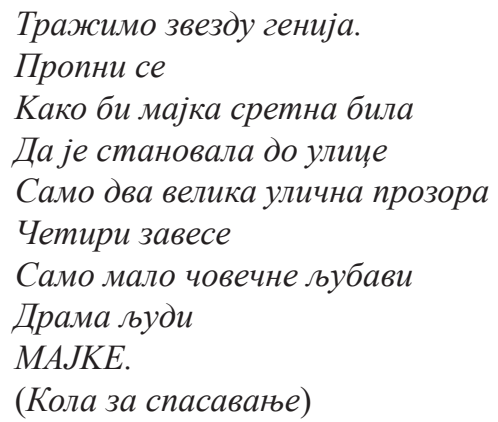

Оно што одмах постаје уочљиво у понуђеном примеру јесте максимална редуцираност стиха. То се углавном постиже скраћивањем реченице на именицу или глагол, који је готово сведен на стенограм тј. „зенитизиран". Такође, изостављени су предлози који повезују стихове и већина интерпункцијских ознака. На овај начин, Мицић чини уступак програмској поставци, по принципима које је Гол дефинисао у тексту Реч као почело...: „Доживљај стегнути на телеграм (...) Сваки стих као реченица стављена у своју властиту атмосферу као телеграфске жице све изоловане и сваки за се носи своју властиту вест...”

Разлика између оваквог доживљаја симултаности и истог феномена у футуристичким стиховима има додуше и један изузетно битан не-програмски разлог, који потиче отуд што је зенитизам до идеје симултаности дошао на специфичан начин, не толико кроз наслеђе раних авангарди, колико под директним утицајем филмског медија. Мицић своју фасцинираност филмом никада није крио: „Непосредно пре и почетком светског рата, био сам дубоко убеђен о надмоћи филмске обухватности, као и данас што сам убеђен да се нова уметност нипошто не може сврстати ван велике основе филмске симултаности. Та филмска симултаност значи: једновремена ритмичка концентрација времена, простора и разноврсних догађаја без обзира на њихову привидну нелогичност... Поново наглашавам да је филм стварно семе зенитистичке поезије, нипошто не ма који други европски покрет, а најмање футуризам" (Мицић 1923 (23): 2).

Овде, дакле, долазимо до суштинског корена зенитистичке песничке форме. У складу са општом авангардном интердисциплинарношћу, „паралелност филмске монтаже послужила је Мицићу као аргуменат у тражењу нових песничких облика" (Маркуш 2003: 103). С друге стране: и овде су опет уочљиви програмски захтеви зенитизма, нарочито они пасажи истог који захтевају да се преко симбола научно-технолошког напретка утиче на свест и целокупни начин размишљања модерног човека, који живи у савремено доба противречности, или Головим речима: „Ми: људи 
прогреса, културе? Но, коме још она импонује, тај нека слегне раменима над Инком... А тако ви мислите: Култура и аероплан? Не, Господине, они немају ништа заједничко. У поређењу са четвртим столећем ми смо само бедни цестари - а ипак не примитивни. Ми бисмо то могли постати... ако усвојимо принцип снажне брзине живота која је изазвана техником а остварена телефоном, експресом зракопловом, ако усвојимо нови осећај деловања и певања. Ако пронађемо нови језик, примитиван за четврто столеће" (Гол 1921 (9): 2).

Међутим, у Мицићевој стваралачкој изведби могу се уочити и неке битне разлике у ставовима двојице зенитиста. Мицић је и иначе дошао у сукоб са Голом, због његове улоге у стварању надреалистичког покрета, додуше у раним фазама истог. У једном есеју објављеном у Зениту, Гол је међу првима употребио термин „надреализам”, одређујући га као алогички елемент (в. Goll 1922 (14): 26). Мицић се генерално и касније противио надреализму (в. Маркуш 1972), а овај сукоб са Голом постаће коначан након премијере његове драме Метузалем у Берлину 1924. Тада ће Мицић прозвати Гола камелеоном европских покрета. Још раније је по Београду кружио примерак Манифеста зенитизма где су имена Токина и Гола била прелепљена налепницом, а њихове странице из интегралног текста одстрањене. Међутим, поетске разлике између ова два аутора се не односе, разуме се, на крајњи циљ њихове поезије, који је заједнички и у складу је са општим зенитистичким оптималним пројекцијама. Те разлике се односе на саму методологију тј. начин доласка до зацртаног циља. По Голу, као што смо видели, свака реченица, сваки стих, морају бити потпуно независни и одељени међусобно, као „телеграфске жице све изоловане." Код Мицића, све ипак зависи од глобалног плана конструкције. У IV вежби Мицић тако указује на „конструкцију примарног осећаја.” Он одбацује тезу античке старине по којој се песма „рађа”. За њега, песма се „ствара”: „... до зенитистичке песме се долази безуветно конструктивним путем: свесно - одређено - геометријски...” У таквој констелацији ствари, потребно је преосмислити основну честицу песничког стварања - реч. Као и Петровић у Младићству народнога генија, као и већина других европских авангардних теоретичара, Мицић посматра реч не само као „реалну реалност” у њеној визуелној или семантичкој природи, него и кроз њен апстрактни смисао, кроз реч као филозофски појам, али и као могућност за асоцијативно мишљење. Када помиње реч схваћену кроз апстрактни смисао, Мицић одмах даје и пример: 
У мојим сновима мртви устају

Возне карте Владивосток - Париз

У сну

Корице су белих хлебова.

Као суштинску карактеристику овако доживљене речи, Мицић наводи њен „еластицитет”. Овај зенитистички појам никако не треба схватити као могућност за какву традиционалну стилску фигуру, као што је нпр. алитерација, нити као симболичку вредност речи. Не треба заборавити да овде имамо посла са једном антиестетиком. Кад год се ради о појму из регистра традиционалне, класичне поетске школе или праксе, то увек припада оном списку вредности које Мицићеви варвари желе заувек да униште. Зенитистичка песма треба да буде сведочанство о бунту и акцији, који воде „до уништења целе старе псеудокултурне поезије 'осећаја' - 'емоције' - 'лепоте'” (Мицић 1922 (13): 17). У шестој вежби свог Категоричког императива... Мицић уводи читав низ забрана, како би зенитистичку песму заштитио од инфицирања формалним вредностима које су се вековима изграђивале кроз класичну, грађанску поезију. Између осталог: „Она (песма - прим. аутора) не сме бити банална! Не сме бити декламаторска, не сме бити фразерска! Не сме бити симболична!” Реч је код зенитиста увек оно због чега је зенитизам аутентична европска авангарда: ексцес, бунт, револуционарна платформа, позив на реакцију, афекат. Па ипак, то је у зенитистичком контексту увек ствар конструкције.

Све ово је свакако разлог што и данас зенитистичка песма делује веома модерно. Она, заправо, антиципира нешто од поезије наших дана, инаугурише поступке којима се савремени песници служе. Почети од средине, краја или почетка песме. Почети од било ког њеног дела. Укључити читаоца и тражити од њега да активно учествује у песничком доживљају самим ишчитавањем. Колико је зенитистичка поезија савремена најбоље ћемо утврдити простом компарацијом. Као примере ћемо узети, с једне стране песму Бранка Ве Пољанског Слепаи број 52, а с друге песму модерног пољског песника Мирона Бјалошевског Ах кад би, кад би чак и пећ однели - моја неисирпна ода радости. Ево Ве Пољанског:

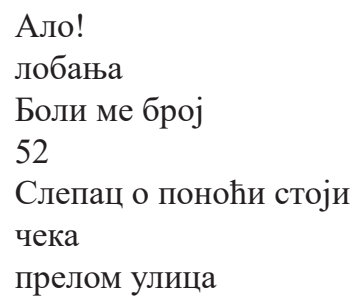


Угао

кабарет

оргијска музика

Кад ће синути дан

кроз црна стакла

слепчевих очала.

Мађионичари руски царски ђенерали

по вечери за 10 динара.

Сена моја вампир мој.

Покварити часовник

време стати

цео свет преобразити

и глупи вашарски

идиоматски

пан

пан

пан

паноптикум

кум

ум

M.

Ово су, пак, стихови, неколико деценија млађег Бјалошевског:

Имам пећ

налик на тријумфалну капију!

Узимају ми пећ

налик на тријумфалну капију!

Вратите ми пећ

налик на тријумфалну капију!

Однели је.

Остала иза ње само

сива

нага

јама.

И то ми је доста:

сива нага јама

сива-нага-јама

си-ва-на-га-ја-ма

сиванагајама. 
У обе песме очигледно је на сцени процес стварања наизглед бесмисленог (можда и „заумног”) језика. Међутим, у обе песме, такође, овај бесмисао постаје смислен, ако се тако може рећи. Другим речима: бесмисао постаје спасоносан, без обзира да ли говоримо о индивидуалном губитку (у савремено доба увек у вези са политиком) који се преображава у пркосну језичку игру или о колективној оптимално пројектованој зенитистичко-авангардној метаморфози целокупне стварности. У оба случаја, превагу односи песничка магија речи.

У зенитистичким песмама можемо видети да је за песму битна и ликовна компонента: геометрија и архитектура облика, графички прелом и типографија. Ово најјасније долази до изражаја у песми бр. 10 збирке Речи у простору, где је стиховни низ деконструисан и увршћен у друге целине. Стога је песма модерна и због своје савремене ликовне естетике. Није стога чудно што поднаслов Категоричког императива... гласи: „Зенитизам - најновији балкански тип конструктивног стварања.” Такође, у самој Мицићевој збирци Кола за спасавање, где је као увод прештампан и Категорички императив..., налази се репродукција нацрта „Споменика Трећој интернационали" руског конструктивисте Владимира Татљина (управо овај рад ће Александар Флакер у Поетици оспоравања именовати као јединствени пример остварене авангардне оптималне пројекције).

Мицићеви ставови из Категоричког императива... везани за песничко стваралаштво, заправо се данас могу посматрати као део општег зенитистичког поетичко-програмског јединства. Ово своју потврду налази у сличности ових Мицићевих ставова са његовим поставкама из области филма и ликовних уметности. Када је реч о филму, већ смо видели да је он филм поставио као темељ зенитистичке поезије и доживљаја уметности. Филм је за њега савршено отелотворење духа зенитизма. Његов брат Бранко Ве Пољански покренуће још 1921. године, заједно са Драганом Алексићем наш први филмски часопис Кинофон - ревија за филмску културу, који ће излазити у дванаест бројева од 15. децембра 1921. до 1. јуна 1922. године и који ће, осим популаризације филмског медија и пропагирања домаћих филмских институција, али и одређених зенитистичких акција, и по стилу и по типографским решењима бити близак зенитистичкој, дадаистичкој и конструктивистичкој форми часописа као авангардног дела. Један други зенитиста ће, међутим, на овом пољу најдаље отићи. Ренесансна личност Бошка Токина ће у себе упити с једне стране зенитистичке теоријске поставке, а с друге фасцинираност покретом, ритмом и динамизмом савременог доба. Он ће управо кинематограф видети као својеврсни „фетиш апарат” модерног доба, а филм као једину 
уметност која може на задовољавајући начин репрезентовати ужурбани дух технолошке цивилизације (в. Токин 1981: 181-183). Наш први филмски критичар и теоретичар, али и значајан филмски стваралац, Токин, свој доживљај филма добрим делом тумачи кроз призму зенитистичких поставки. Међутим, да се ради о аутентичном авангардисти сведочи већ први српски чланак посвећен теорији филма, Токинов текст Покушај једне кинематографске естетике (првобитно објављен у чувеном француском часопису L'Esprit Nouveau 1920. године, а потом преведен и објављен у београдском Прогресу 1921), у коме се магија филма деконструише кроз одређене поставке француске и италијанске авангарде. Циљ овог значајног есеја биће да се филм промовише као суштински интердисциплинарни, па самим тим и авангардни, уметнички облик, о чему још, према Токиновим речима, код нас није била сазрела свест. Можемо додати да та свест није била сазрела нигде, јер у то време још нико није промишљао филм на начин естетике. Овај есеј данас нам говори о једној значајној визији и напредној мисли истинског визионара, с обзиром да је писан у време када су се Грифит или Чаплин тек етаблирали као филмски класици, када је Канудо осмислио израз „седма уметност” и када Холивуд само што није ушао у своје најславније раздобље. „Кинематограф је учинио да данас спознајемо природу и земљу. Сада почињемо, улазећи у нову фазу његовог развоја, да мало боље упознајемо унутрашњост своју. Обухватили смо земљу, видљив свет, а сада обухваћамо све више и више, онај други, мање видљив" (Токин 1981: 231). Уз обиље цитата и термина највећих филмских стваралаца тог времена (Дзига Вертов, Абел Ганс, Михаил Ејзенштајн) овај, као и други филмски есеји Бошка Токина (пре свих Eстетика филма, али и нпр.: Филм је музика светлости, Кино снова и поезије, Photogenie, U. S. A. = Poe, Whitman, Chaplin), сведоче о великој информисаности овог аутора о феномену филма, али и његовом специфичном поетском (добрим делом зенитистичком) доживљају филма као оног стваралачког медијума који ће објединити поезију, науку и филозофију, где ће се преко филма језиком поезије проговорити о идејама науке и уметности. Или Токиновим речима: „Кинематограф је нашао начин да се напишу ненаписане песме” (Токин, Исто). Користећи визионарске теорије зенитизма, по којима је само филм способан да визуализује истину (в. Даковић 2010: 101-104), Токин ће се, то данас треба наглашавати, приближити идејама које ће тек неколико деценија касније постати доминантне у тумачењу филмске уметности, захваљујући капиталној студији Едгара Морена Филм или човек из маште, из 1956. године.

Иначе, Токинова филмска пракса, која, нажалост, није сачувана (или још није пронађена), обухвата један започети роман, који је био писан и 
замишљен као филм под називом $У$ краљевству духова, као и сценарио и режију никада довршеног филма Качащи у Топчидеру или Буди Бог с нама. Рад на овом филму обухватио је неколико ондашњих авангардиста. Пре свих, први Токинов сарадник је био Драган Дада Алексић. На конкурсу за сценарио је победио Бранимир Ћосић, снимање је трајало један дан, после чега су потрошена расположива средства, док је сам материјал нестао (в. Лепосавић 2001). Такође, Токинов најпознатији роман Теразије (1932) структуриран је по узусима филмског језика.

Када је пак реч о зенитистичком промишљању ликовне уметности - и ту је јасан суштински интердисциплинарни концепт овог покрета. Укратко: супрематизам је ликовну уметност довео до апсурда. Малевичев Бели квадрат на белој основи представља крајњу консеквенцу овакве уметности. Култура тоталног раскида с традиционалном парадигмом овим је дошла до свога конца и сада је требало кренути даље, у правцу глобалне уметничке оптималне пројекиије. Године 1919, Казимир Малевич потписује платформу УНОВИС-а (Утврђивање нове уметности - прим. аутора). Том приликом ће истаћи да „свеукупно стварање изума, њихова реализација, конструкција, систем има да се развијају на основи пете димензије.” Пета димензија је била - економија. Како читаоце Зенита извештава сам учесник у тим процесима Ел Лисицки, овим су ударени темељи „конструктивном смеру који је проистекао из двају основних група обележених Татљином и Малевичем" (Еренбург-Лисицки 1922 (17/18): 50).

Још из Манифеста зенитизма јасна је Мицићева тежња да синтетише искуства раних европских авангарди и превазиђе их новим, тоталним стваралачким поступком. Том идеалу он посвећује цео свој стваралачки пут. На путу ка том идеалу, он у песничкој теорији, као и у погледима ка ликовним уметностима, као бит стваралачких поступака види „конструкцију”. И то „конструкцију” која мора да рачуна са савременим тековинама цивилизације: „Нови сликар треба да конструише, те заједно са инжењером ствара онаква дела, која ће као реалност послужити не само као докуменат уметничке и културне вредности, него и људима који живе у заједници било градова, било железница или аутомобила" (Мицић 1923 (21): 1). Поетика „реалног артефакта” у српској културалној пракси, дакле, овде има своје почело. Антиципација примењене уметности такође је очигледна. Да ли је у овим ставовима било утицаја руског конструктивизма? Несумњиво. Међутим, тон и оригиналност Мицићевих ставова, као и снага његове визије, сведоче нам изнова о теоријској и стваралачкој аутентичности вође зенитистичког покрета. 
Одбацујући сваку зависност уметничког дела од природе, Мицић је, на примеру Архипенкових скулптура будући циљ и израз уметности видео у „оптикопластици”. „Зар је збиља циљ уметности тако инфериоран да посредник ('уметник') преводи готове предмете живе - природе у мртву природу скулптура, слика, песама (...) Не више метафизика и апстракција, него физика и реалност нових форма које се откривају и које настају на путу ка колективном стилу. Ка путу према чистој Оптикопластици!” (в. Мицић 1923). Овде се, заправо, ради о првој европској антиципацији онога што ће читаве четири деценије касније, пре свега захваљујући Вазарелијевим радовима, постати глобално познато као оп-арт.

Истоветност Мицићевих ставова поводом песничке, филмске и ликовне зенитистичке школе потврђује се простом компарацијом његових текстова о овим проблематикама. Баш као што се симултаност и конструктивизам очитују у стиховима зенитистичке поезије, тако на пример и у будућој оптикопластици „симултана концентрација разнородних елемената у једној јединој уметничкој креацији пружа реалан доживљај... Нова пластика треба да је реални чин, доживљај симултаних оптичких предмета, који тек у заједници, а по уметниковој стваралачкој вољи сачињавају уметничко дело у одређеном простору...” (Мицић Исто). Слично томе, у петој вежби Категоричког императива..., Мицић наглашава значај конструктивног метода: „Зенитистичком конструкцијом постиже се јединственост и једноставност сваког облика у простору.”

Време и простор - једна од опсесивних тема филозофије и уметности XX века - у зенитистичкој поезији, али и укупној поетици зенитизма, добили су јединствено и аутентично тумачење. Наиме, с обзиром на то да се догађаји у зенитистичкој поезији или слућеној преферираној ликовној уметности, дешавају симултано, укинута је њихова хронологија, те у зенитистички схваћеном простору - нема времена, као појма који се изводи на основу хронолошког односа кретања. Тиме је одбачена свака ограниченост, а уметност постаје - „апсолутно стварање” (Мицић 1923 (22): 2), под доминантним утицајем конструктивног елемента. Стога је назив Речи у простору, који се односи на збир првих Мицићевих зенитистичких песама, веома симптоматичан и добро одабран.

Зенитистичке конструктивистичке поставке ће у области ликовних уметности, поред самог Љубомира Мицића, најбоље својим радовима представљати још и Михаило С. Петров и Јо (Џо) Клек (Josip Seissel). Овај други ће на основу зенитистичких поставки засновати сопствену праксу апстрактног сликарства која ће се кретати „између рroun естетике Ел Лисицког, Малевичеве визије супрематизма и новог пластицизма Де 
Стијла" (Шуваковић 2010: 91). Његова дела, која се уклапају у апстрактне зенитистичке колаже, биће називана Пафаме (на немачком: PApier-FArbenMAlerai) - што је сам Клек смислио да означи зенитистичке ликовне експерименте; или у складу са зенитистичком терминологијом Арбос (АРтија-БОја-Слика) - што је Мицићев термин. У сваком случају, овакав доживљај подразумева слику као аутономну конструктивистичку творевину, која представља тоталитет за себе, која је омеђена својим пикторалним простором и означена као изразито немиметичка, заснована на економији материјала, рада и деловања, у складу са наведеним Малевичевим захтевима. То је и разлог због кога је оснивач зенитизма само Јоа Клека и Михаила С. Петрова сматрао зенитистичким сликарима.

Међутим, конструктивизам ће бити управо онај сегмент који ће зенитистичку поезију, у поетичком смислу, оштро издвајати од поезије дадаизма или надреализма. За дадаизам као бихевиоралну уметност, у којој је понашање уметника у свом окружењу готово битније од самог уметничког чина, конструктивизам није могао имати онај значај који је имао за зенитизам. Када је реч о надреализму, његово је стваралаштво засновано на „реторици несвесног” или још боље - на „медијском несвесном”, где су оптички, текстуални, визуелни или аудио-визуелни материјали структурирани тако да покажу нетранспарентност презентације и медијског посредовања значења. Тамо где је несвесно структурирано као медиј нема потребе ни за каквом конструкцијом, тим пре што је једна од основних техника надреализма: аутоматизам. Изглед тако добијеног стваралачког дела није, дакле, последица намере, него последица несвесног. Иако у самим поетикама дадаизма и надреализма има одређених пукотина, као могућности за конструкцију унутар њих (као уосталом што и у случају зенитизма постоје пукотине као могућности за деловање несвесног), по свим елементима присутним у овим поетикама - ради се о заједничкој особини: пуном опсегу настојања авангардног стваралаштва: од културе тоталног раскида до оптималне пројекиије.

Додуше, када је реч о надреализму, ситуација је прилично компликована, јер је тај покрет започео своје деловање негде између радикалних елемената авангарде и високо естетизованог грађанског модернизма, да би се преко својеврсног фројдомарксизма већ тридесетих година определио као противник модернистичких и авангардних струјања и на крају завршио у духу етаблиране псеудореволуционарне уметности социјалистичког реализма. Све то, разуме се, не би са уметничке тачке било проблематично, да надреализам у овим процесима није пресекао све везе са ранијим авангардним поетикама (у српском контексту: зенитизам, дадаизам, Растко 
Петровић) и тиме лажирао и саме темеље сопствене поетике. Међутим, снага авангардних пасажа у оквиру српског надреализма, јасно сведочи о утицајима претходних српских авангарди на формирање поетике овог покрета, утицајима у којима, поред других поетичких тонова, није тешко препознати и оне зенитистичке.

Уосталом, не треба, у том контексту, сметнути с ума једну код нас мање познату чињеницу, која остаје велико глобално отворено питање када је реч о самој иницијалној тачки надреализма. Наиме, након разлаза са Љубомиром Мицићем, Иван Гол ће 1924. године у Паризу покренути часопис недвосмисленог назива: Surrealisme; и окупити око њега изузетно значајне сараднике као што су: Гијом Аполинер, Рене Кревел, Пол Дерме, Пјер Реверди, Марсел Арлан итд. У том часопису Гол ће дати прву дефиницију надреализма, пре оне из Бретоновог Манифеста... Очигледно сматрајући да је право првенства на његовој страни, Гол је ушао у отворени сукоб са Бретоном, који ће резултирати Бретоновим приматом у надреалистичким круговима и међусобним престанком комуникације, све до послератних година, када су се измирили у заједничкој емиграцији у САД. Оно што је у читавој овој ствари за нас битно, јесте да је Гол у својој дефиницији надреализма, изрекао мноштво зенитистичких ставова (каткад сасвим дословно), а очигледна је и промена одређених гледишта у погледу конструктивизма. Наиме, у својој почетној „головској” фази, надреализам је у великој мери био конструктивистички покрет, са сасвим јасним и Голу блиским зенитистичким елементима. Уосталом, као што смо већ видели, Гол је још раније у Зениту објавио текст Надреализам и алогика нове драме, у коме се бави тумачењем појма надреализам, кога је у орбиту књижевних студија први лансирао Гијом Аполинер, у једном предавању из 1917. године. Такође, треба рећи и да је у самом Манифесту зенитизма Бошко Токин био тај који је први код нас говорио о „надреалном". То се у првом реду односи управо на конструктивистичке елементе мицићевско-зенитистичке поетике.

III

Ова поетика се, природно, није исцрпела превасходно у личном стваралаштву Љубомира Мицића и Ивана Гола. Постоји читава плејада песника, сликара и других уметника који су по начелима зенитистичке уметничке платформе стварали своју креацију. На првом месту, то је највернији пратилац оснивача зенитизма, његов рођени млађи брат, Бранко Ве Пољански, покретач првог чисто авангардног часописа на на- 
шим просторима (Светокрет, Љубљана, 1921) и нашег првог филмског часописа, као и антидадаистичке публикације Дада-Јок. Објавио је три збирке песама: Паника под сунщем (1924), Тумбе (1926) и Црвени петао (1927), као и пре тога роман: 77 самоубица: Невероватна љубавна збитија господина Никифора Мортона. Веома брз надфантастични роман (1923). Мање филозоф од свог брата, више присталица „ванумних” стваралачких активности и примарних песничких сензација, његове песме поштују зенитистичке постулате, али су истовремено блиске аутоматском писању или лирској фантазмагорији. Био је човек од поверења зенитизма, па је као такав често путовао развијајући контакте покрета - од раног боравка у Прагу и сарадње са Драганом Алексићем, преко пута у Берлин на „Прву руску уметничку изложбу" (1926), где ће упознати Шагала, Архипенка и Херварта Валдена, или преко Париза где ће 1925. учествовати у чувеном полемичком дијалогу са Маринетијем (в. Зенит 1925(37): 6), све до пута у Москву на „Изложбу револуционарне уметности Запада” (1926) или штампања опширног информативног чланка о зенитизму у холандском Де Стијлу.

Иако још 1927. године, у уводу збирке Црвени петао, Пољански пише о својој верности зенитистичком покрету, већ од 1925. године тј. од његовог преласка у Париз, где као аутодидакта почиње да се бави сликарством, приметно је извесно одвајање од интегралног зенитизма. Додуше, он се испочетка представљао као заступник часописа Зенит и самог зенитистичког покрета, али већ само његово сликарство, започето тих година, било је део онога што се у тадашњем Паризу називало „повратак реду”. Ускоро ће његово одвајање од тврдог зенитизма и радикалне уметничке праксе постати очигледно. Још 1928. је био илустратор књиге његовог брата Hardi! A La Barbarie, али након тога разлаз постаје очигледан. У Манифесту панреализма (1930) Пољански се враћа „самом сликарству” директно се супротстављајући авангардистичким захтевима за „неприказивачким" сликарством, залажући се за сликарски мимезис и реализам који захвата сву сложеност света или панреалност: „Размишљања о сликарству доводе природно, после панреализма, до негирања савременог фетишизма, који је постао, на несрећу религија помодних скоројевића" (Пољански 1974: 23).

Можда ће овај отклон од радикалних зенитистичких захтева бити и разлог да Љубомир Мицић, у интервјуу Зорану Маркушу, више пута понови како он нема брата. После раних 30-их година, Пољански се више неће појављивати у јавности. Живеће породичним животом у великом сиромаштву. Умреће у Фонтенблоу, надомак Париза, 1947. године (в. Голубовић 1996: 146-156). 
Ристо Ратковић је још један зенитистички песник, кога често, уз извесне ограде, сврставају и у надреализам. Сам Ратковић о себи пише: „На моју еволуцију утицао је у првом реду зенитизам. То сам признавао и себи и другима, чак и онда када нисам помишљао на сарадњу са зенитистима... Осетио сам да се у зенитизму може врло лако изразити оно најелементарније у модерном духу, управо оно чиме је тај дух условљен - револуција. Све зенитистичке „догме” схватио сам само као колективну дисциплину, да би револуција била што већа и као такву је примио, задржавајући, при том, своју индивидуалну слободу" (Ратковић 1926). Затим, ту су и зенитистички женски сарадници од којих су директно суделовале у покрету: хрватско-аустријска уметница Вјера Билер, Нина-Нај Мицић (Анушка Кон Мицић), животна сапутница Љубомира Мицића, као и супруга Ивана Гола и негдашња љубав Рајнер Марије Рилкеа (који јој је посветио и једну песму) - Клер. Потом, треба поменути Франца Рихарда Беренса, негдашњег Штурмовог песника, који је заједно са Иваном Голом иступио из експресионистичког покрета и придружио се зенитизму.

Ту су и многи други занимљиви зенитистички аутори. Двојица од њих, међутим, заслужују посебну пажњу. Први је Маријан Микац, који је у оквиру зенитизма објавио прозне текстове Ефект на дефекту (Београд, 1923) и Феномен мајмун (Београд, 1925), са илустрацијама на корицама од стране Јо Клека. Форма његове прозе представља полижанровски авангардни текст, а у Петрињи и Сиску је био укључен и у конкретне зенитистичке акције. Касније, 20-их и 30-их година се бави новинарством и објављује два популарна романа, Под теретом ленгера (Београд, 1926) и Доживљаји Морииа Швариа у Хитлеровој Немачкој: сатиричан роман (Загреб, 1937). Последњи роман је писан на сличан начин на који је Бошко Токин написао Теразије, са пуно „филмичних” детаља и реквизита. Сам Микац је једно време радио за „20 Century Fox Film” и „Paramount Pictures”. Касније бива један од главних организатора филмске продукције Независне државе Хрватске, да би након рата и хапшења успео да побегне, прво за Италију, па у Аргентину. На крају се за стално настанио у Аустралији. Неко време је боравио у Франковој Шпанији. Управо враћајући се одатле за Аустралију, умире на броду 1972.

Други изузетно занимљив зенитистички аутор јесте својеврсна урбана мистерија Београда. Стваралац потписан као Мид објавио је две зенитистичке књиге, Метафизику ничега (1926) и Сексуални еквилибријум новиа (1926). Такође, објавио је и три прилога у самом часопису Зенит. Његове књиге представљају један од врхунаца експлицитног авангардизма, у коме се књига поставља као медиј уметничко-авангардног експеримента, али 
и исказа. Колажно-монтажно повезивање речи и слике, у зенитистичком маниру, нарочито томе доприноси. Међутим, чак и у оквиру радикалне уметничке праксе зенитизма, Мидове књиге представљају куриозитет. „Оно што Мидове књиге чини битним доприносом 'мистерији о аутору' јесте њихова неконтекстуализованост. Оне су, за разлику од других зенитистичких књига које имају књижевни статус, без обзира на радикалне иновације или трансгресије, заиста неизвесни артефакти писања. Мидове књиге немају предочене референце ка књижевним жанровима, већ јесу презентација самог 'графичког' писања које се креће између визуелног и вербалног" (Шуваковић 2010: 98). Штавише, додали бисмо, својом типографијом, Мидове књиге превазилазе вербализам минималистички представљеним малим и великим, црвеним и црним крстовима (у Метафизици ничега) или цифрама (у Сексуалном еквилибријуму новиа), чиме се указује на прелазак из света симболичких ознака у свет самих знакова. И поред појединих написа о њему и одређених претпоставки (в. Ратковић 1928; Костић 1972, Шуваковић 2010), Мидов идентитет никада није утврђен. За разлику од Микца, кога је тек модерна кроатистика стала поближе проучавати (в. Донат 1993), о Мидовом веома интересантном авангардном завештању српска наука и уметничка историја још није исписала ни ред.

Оно што остаје, када је о комплетном зенитизму реч, несумњива чињеница јесте немерљиви и ни до данас недовољно наглашени значај зенитизма као међународно признатог, а аутентично домаћег авангардног покрета; и то у двоструком смислу: културално-историјском и футуролошком. Наиме, са једне стране, зенитизам је био интернационални покрет у најбољем смислу те речи. О њему се знало и писало у свим водећим културалним престоницама Европе, од Москве и Прага, до Париза и Лондона, али и у Аргентини и у Јапану (о зенитизму је писано, на пример, у јапанском часопису Mavo (в. Маркуш 2003: 107)). Најбитнији и најпрестижнији часописи ондашњег света, гласила интелектуалних и уметничких кругова који су стварали културну климу треће деценије XX века, пишу о зенитизму (Sturm, De Stijl, Ma, Predmet, Contimporanul, Transition, Het Oversicht итд.). Зенитистичко гласило Зенит био је у то време једини европски часопис који је своје прилоге штампао на оригиналним језицима, визуелни идентитет часописа је до данас непревазиђен (нарочито ако се зна да је сваки број овог часописа штампан на другачијој хартији), а од списка имена која су сарађивала у овом часопису, данас - када се навршава готово цео век од зенитистичке буре - наши часописи који се баве културом и уметношћу могу само да сањају. Списак Зенитових сарадника није ништа друго до ли списак најзначајнијих културних посленика и 
стваралаца Европе онога времена. Готово да нема значајнијег имена, на било који начин везаног за европску авангарду, да није потписник неког прилога Зенита. Уосталом, чувени амстердамски часопис De Stijl га је уврстио у један од пет часописа из читавог света који је пресудно утицао на општи развој авангарде. У том смислу, у имагинарном координатном систему наше културалне мапе XX века, кривуља би на одредници „зенитизам” сасвим сигурно била на једном од својих врхунаца.

С друге стране, налик Кандинском из дела $O$ спиритуалном у уметности, Мицић је, такође, један од авангардиста са грандиозном сликом оптималне пројекиије. Његова антиципација оп-арта, као и неких од круцијалних елемената надреализма, али и глобалног утицаја науке и технике на естетику савременог стваралаштва, сведоче о големом футуристичком таленту $^{3}$, а пасажи о модерном животу појединца нам указују на филозофску моћ реалног сагледавања стварности са перцепцијом долазећих дешавања. Његове идеје о будућности ликовних уметности, у великој мери потакнуте руском конструктивистичком уметношћу (превасходно Архипенковим скулптурама), мораће да сачекају неколико деценија да би се у индустријски развијеном друштву дошло до технолошких могућности за развој и уметничку обраду ових идеја. ${ }^{4}$

Такође, када је реч о његовој издавачкој пракси, она нам данас сведочи о једном - чак и за наше доба - модерном поступку доживљавања књиге (или часописа) као медија. Авангардна књига или часопис тако не служи само простој комуникацији и презентацији одређених уметничких концепата, него представља масовни и репродуктивни медиј по себи, који може комуницирати модерно културно окружење у целини. Интердисциплинарна форма ових авангардних дела само доприноси томе. „Битно је да се уочи да су и часописи Zenit, Dada Tank, Dada Jazz, као и књиге Мицића, Пољанског, Микца и Мида експлицитно модерне књиге које својом полижанровском, колажно-монтажном, визуелно-вербалном структуром одсликавају или симулирају језик масовних медија, пре свега, радија, филма и рекламне индустрије” (Шуваковић 2010: 98, 99). Зато нам је то

${ }^{3}$ Упоредити: „Новим уметницима нису непознати закони геометрије, физике, оптике, статике или машинске конструкције. Све су то елементи, који, без икаквог чуђења условљавају свакодневну равнотежу у техници живота - елементи који су врло омиљени новим уметницима у њиховим делима поред сасвим реалних предмета из природе: дрва, гвожђа, камена, стакла, мермера, плеха и др. Нови уметници с правом се спремају на изградњу једне велике, нове и боље епохе човечанства" (Мицић 1924 (34): 4).

${ }^{4}$ Упоредити: „, Механика је, ван сваке сумње, постигла много веће и завидније резултате. Техника је победила целу данашњу уметност... Уметници! Не заборавите првокласне ортопедијске скулптуре. Када ћемо доживети скулптуру аероплана или пластику електро-радио-централа" (Мицић 1923). 
данас изузетно драгоцено, јер ова дела представљају, у контексту српске и југословенске стваралачке праксе, најјаснију антиципацију савременог корпоративног, потрошачког друштва и растуће world wide културалне индустрије.

Разуме се, будући да није припадао некој од великих европских култура, а и да га се његова матична култура на сопствену срамоту готово одрекла, име Љубомира Мицића ће бити заобиђено у развоју модерног европског арт-а. Разлог више, чини се, за његову нову афирмацију и ревалоризацију. Иако човек тешког карактера, Љубомир Мицић је без сумње један од највећих визионара кога је српска авангарда, али и много шира културна сцена XX века, имала. Уосталом, савремена обнова интересовања за овог чудесног ствараоца није случајна.

У средини где је објавио своје присуство свету, баш попут централног дискурса своје поетике - дискурса парадокса, зенитизам није имао ни минималне предуслове за дуг живот. „Величина великих могућа је само у једном културно формираном друштву” - жалиће се 1927. године Бранко Ве Пољански, који ће најбоље то на својој кожи осетити, као потоњи париски клошар, чији чак и гроб остаје непознат. Као да речи надреалисте Ђорђа Костића посвећене мистериозној личности зенитистичког ствараоца Мида, личности која би у великој мери могла бити симбол најрадикалнијих домета српске авангарде, остају трајно сведочанство које би се могло проширити на цео зенитизам: „Његове књиге су се могле видети само у једној папирници. Ја сам купио обе. (...) Мид је, иза те две књиге, као иза стакленог зида стајао и покретао уснама, намигивао, правио гримасе, али га нико није чуо. Био је нем. Он је дошао одвећ рано" (Костић 1972: 27).

Па ипак, авангардна дела Архипенка, Татљина, Лисицког или Рођенка и читава руска конструктивистичка авангардна поетика, која ће по свему највише утицати на Мицићево развијање идеја о будућности уметности, управо доживљавају у савременом арту своју пуну ревалоризацију и освајају нове сфере стваралачког утицаја. Са већином ових уметника, Мицић је, природно, у своје време сарађивао. Ипак, зенитизам - као дисперзиван покрет стваралаца и као платформа за будућу уметност, али и као чин фанатизма једног човека - своју јединственост у контексту европске авангарде, у пуном опсегу достиже својом поетиком варварства, као категоричким императивом своје стваралачке школе, али и као својеврсним conditio sine qua non општег развоја човечанства. Главни зенитистички и последњи романтични јунак Европе - Барбарогеније - и даље корача својим грандиозним корацима, без обзира да ли га ми доживљавамо у уско националним или глобалним трендовима, напоредо са доминантном 
европском културалном праксом, као истинска алтернатива сваком савременом уметнику и неком будућем стваралачком прегнућу.

\section{ЛИТЕРАТУРА}

Биргер 1998: P. Birger, Teorija avangarde, Beograd: Narodna knjiga, Alfa. Флакер 1984: A. Flaker, Poetika osporavanja, Zagreb: Školska knjiga.

Гол 1921: И. Гол, Реч као почело - покушај нове поезије, Зенит, 9/1, Загреб, 2.

Голубовић, Суботић 1983: V. Golubović, I. Subotić, Zenit i avangarda dvadesetih, katalog, Beograd: Narodni muzej.

Голубовић, Суботић 2008: V. Golubović, I. Subotić, Zenit: 1921-1926, prevod na engleski Novica Petrović, fotografije Miodrag Đorđević, Beograd: Narodna biblioteka Srbije, Institut za književnost i umetnost, Zagreb: SKD Prosvjeta.

Гpojc 1991: B. Groys, Nitssheanskie temy i motivy v sovietskoi kulture 30-ih godov, u: Kujundžić, Dragan, The Returns of History - Russian Nietzcheans AfterModernity, New York: SUNY Press.

Еренбург-Лисицки 1922 (17/18): I. Erenburg, E. Lisicki, Ruska nova umetnost, Zenit, 17-18, 2: Zagreb.

Јованов 1999: J. Jovanov, Demistifikacija apokrifa: dadaizam na jugoslovenskim prostorima 1920-22, Нови Сад: Apostrof.

Константиновић 1983: R. Konstantinović, Ljubomir Micić, u: Biće $i$ jezik: u iskustvu pesnika srpske kulture XX veka, knj. 5, Beograd - Novi Sad: Prosveta, Rad, Matica srpska.

Маркуш 2003: 3. Маркуш, Zenitizam, Београд: Сигнатуре.

Мицић 1921 (1): Lj. Micić, Čovek i umetnost, Zenit, 1,1: Zagreb.

Мицић 1922 (13): Lj. Micić, Kategorički imperativ zenitističke pesničke škole, Zenit, 13, 2, Zagreb.

Мицић 1925 (37): Љ. Мицић, Мароко и опет за спас цивилизације. Империјализам је библија Европе и Европејаца, Зенит, 37, 5, Београд.

Мицић 1926 (41): Љ. Мицић, Мој сусрет с Анри Барбисом, Зенит, 41, 6, Београд.

Мицић 1924 (34): Љ. Мицић, Нова уметност, Зенит, 34, 4, Београд.

Мицић 1923: Lj. Micić, Prema optikoplastici, u Micić, Ljubomir, Arhipenko - nova plastika, Beograd.

Мицић 1921 (3): Lj. Micić, Putujući ekspresionizam i Anti-kulturni most, Zenit, 3, 1, Zagreb. 
Мицић 1921 (10): Lj. Micić, Savremeno novo i slućeno slikarstvo, Zenit, 10, 1, Zagreb.

Мицић 1926: Љ. Мицић, Ванумна поезија и Антиевропа, у: Мицић, Љубомир, Антиевропа, Београд.

Мицић 1923 (21): Lj. Micić, Zenitizam kao balkanski totalizator novog života i nove umetnosti, Zenit, 21, 3, Zagreb.

Мицић 1922 (11): Lj. Micić, Zenit manifest, Zenit, 11, 2, Zagreb.

Суботић 1981: И. Суботић, Сећања на сусрете са Љубомиром Мицићем, Книжевност, 7, 8, Београд.

Суботић 1990: I. Subotić, Zenit and Zenitism, The Journal of Decorative and Propaganda Arts, Miami, Fall.

Шуваковић 2010: M. Šuvaković, Eklektični avangardizam: Zenit, u: Istorija umetnosti u Srbiji XX vek: prvi tom, radikalne umetničke prakse, ur. Miško Šuvaković, Beograd: Orion art i Katedra za muzikologiju Fakulteta muzičke umetnosti.

Тешић 2009: Г. Тешић, Српска књижевна авангарда: књижевноисторијски контекст (1902-1934), Београд: Институт за књижевност и уметност, Службени гласник.

Vasilije K. Milnović

NOISE OF BARBARIANS: A CONSISTENT RADICAL ARTISTIC PRACTICE OF ZENITISM

\section{Summary}

The topic of this paper is to reflect the range and scope of zenitism as one avant-garde theoretical platform that in the most convincing manner testifies about disintegration that occurs within the overall Serbian avant-garde - modernism paradigm. Consistency and radicality of zenitistic creative practice, is one that affirms the uniqueness zenitism in the context of the European avant-garde, and Serbian cultural matrix. In this way, the point is a real need for reassessment zenitists creation, both in its theoretical consideration - explicit, and implicitly the very creative - embodiment. This is especially true with regard to the timeliness and creative practice in relation to contemporary art trends and considering the authentic character of the projective-futurological zenitism.

Key words: Zenitism, Zenit, Ljubomir Micić, manifest, a culture of total rupture, optimal projection, interdisciplinary. 